\title{
Opportunistic suspension feeding in the intertidal gastropod Olivella columellaris and its implications for the regulation of tidal migrations
}

\section{Alimentación suspensívora oportunista del gasterópodo intermareal Olivella columellaris y sus implicaciones en la regulación de las migraciones mareales}

\author{
Aaron P Morse ${ }^{1}$, Winfried S Peters²,3* \\ ${ }^{1}$ Department of Geosciences, Indiana/Purdue University Fort Wayne, 2101 East Coliseum Boulevard, \\ Fort Wayne, IN 46805, USA. \\ 2 Department of Biology, Indiana/Purdue University Fort Wayne, 2101 East Coliseum Boulevard, Fort Wayne, \\ IN 46805, USA. \\ ${ }^{3}$ Goldring-Gund Marine Biology Station, Playa Grande, Santa Cruz, Guanacaste, Costa Rica. \\ * Corresponding author. E-mail: petersw@ipfw.edu
}

\begin{abstract}
The gastropod Olivella columellaris inhabits sandy beaches of the Tropical East Pacific. These snails perform tidal migrations for continuous suspension feeding in the moving backwash zone, possibly controlled by an endogenous circatidal clock. However, O. columellaris readily modifies its circatidal behavior, for example when flow channels develop below natural and artificial tide pools at ebb tide. Suspension feeding continues in such channels while water is running, delaying tidal migration. Such behavioral plasticity questions the significance of endogenous rhythms for the regulation of tidal migrations in O. columellaris.
\end{abstract}

Key words: Olivella columellaris, sandy beach intertidal zone, underwater sailing locomotion, endogenous clock, tidal migration.

RESUMEN. El gasterópodo Olivella columellaris habita las playas arenosas del Pacífico Oriental Tropical. Estos caracoles suelen realizar migraciones mareales ya que se alimentan de partículas en suspensión en la zona de resaca que se mueve con la marea. Aunque este comportamiento posiblemente esté regulado por un reloj endógeno que sigue los ritmos mareales, O. columellaris fácilmente puede modificarlo. Por ejemplo, cuando se crean pequeños canales que drenan el agua de las pozas (naturales o artificiales) generadas en marea baja, la alimentación suspensívora continúa mientras el agua esté corriendo, retrasándose así la migración mareal. Dicha plasticidad en el comportamiento cuestiona la importancia de los ritmos endógenos en la regulación de las migraciones mareales de O. columellaris.

Palabras clave: Olivella columellaris, zona intermareal de playas arenosas, locomoción subacuática por vela, reloj endógeno, migración mareal.

\section{INTRODUCTION}

The behavior of the inhabitants of intertidal zones is linked to the predictable tidal cycles, and the involvement of endogenous clocks has been demonstrated in several species (Naylor 2010). Especially in mollusks, however, the distinction of endogenously controlled circatidal behaviors from direct responses to tide-dependent changes of external stimuli has proven difficult. For instance, the tide-related behavior of Hydrobia ulvae, an abundant gastropod of European estuarine habitats, has been scrutinized for half a century with equivocal results (Newell 1962, Little and Nix 1976, Barnes 1986, Vieira et al. 2010). Other examples are the large-scale tidal migrations of certain sandy beach mollusks, which appear highly adaptive in the intertidal environment. Nonetheless, it seems that mollusk tidal migration is "not synchronized by an intrinsic mechanism but results from behavioral responses to changing physical conditions" (McLachlan et al. 1979: 433; see also Ansell 1983, McLachlan and Hesp 1984, Ellers 1995a, 1995b).

\section{INTRODUCCIÓN}

El comportamiento de los habitantes de las zonas intermareales está vinculado a los ciclos predecibles de las mareas, y se ha demostrado el papel de los relojes endógenos en varias especies (Naylor 2010). No obstante, especialmente en el caso de los moluscos, ha resultado difícil diferenciar entre comportamientos controlados de manera endógena y respuestas directas a estímulos externos. Por ejemplo, el comportamiento relacionado con la marea de Hydrobia ulvae, un gasterópodo abundante en hábitats estuarinos de Europa, ha sido estudiado durante medio siglo con resultados ambiguos (Newell 1962, Little y Nix 1976, Barnes 1986, Vieira et al. 2010). Otros ejemplos son las migraciones mareales a gran escala de algunos moluscos que habitan playas arenosas, los cuales suelen ser altamente adaptables en el ambiente intermareal. Sin embargo, la migración mareal de los moluscos "no está sincronizada por un mecanismo intrínseco sino por respuestas conductuales a condiciones físicas cambiantes” (McLachlan et al. 1979: 433; ver además Ansell 1983, McLachlan y Hesp 1984, Ellers 1995a, 1995b). 
Olivella columellaris (Sowerby 1825) and O. semistriata (Gray 1839) (Olivellidae, Caenogastropoda) are common sandy-beach gastropods of the tropical American west coast (Olsson 1956) with unusual feeding habits. Both species use 2 pairs of lateral appendages, which are not found in other Olivellidae, to expose semispherical mucus sheets to flowing water (Troost et al. 2012). The mucus, together with captured plankton and detritus, is eaten in short intervals (Seilacher 1959). So far, this mode of suspension feeding has been noted only in the backwash zone of sandy beaches. Since this zone moves with the tide, efficient feeding requires tidal migrations, which both species achieve by using their expanded feet as underwater sails. It seemed plausible to interpret underwater sailing locomotion and suspension feeding as functionally linked elements of a specific adaptation to the conditions in the sandy beach intertidal zone (Schuster 1952, Schuster-Dieterichs 1956, Seilacher 1959, Friedrich 1969: 270), leading to the claim (Vanagt et al. 2008) that an endogenous circatidal clock is crucial for explaining the observed migration patterns (all these authors confused O. semistriata and O. columellaris; see Troost et al. 2012).

Extreme densities of $O$. columellaris are characteristic of northern Peruvian beaches (Olsson 1924; compare Ramírez et al. 2003). Here we report observations from this region which suggest that the migration and suspension-feeding behavior of this species are more versatile than previously thought.

\section{MATERIALS AND METHODS}

In August 2013, we studied O. columellaris during field trips along the coast of the Department of Piura, Peru, and conducted systematic observations north of the village Colan $\left(4^{\circ} 59^{\prime} \mathrm{S}, 81^{\circ} 4^{\prime} \mathrm{W}\right)$. To determine local densities, short $(20 \mathrm{~cm})$ rigid plastic pipes of 28,14 , or $10 \mathrm{~cm}$ diameter were pushed into the sediment to $8 \mathrm{~cm}$ depth, the pipe contents were collected and sieved ( $5 \mathrm{~mm}$ mesh), the $O$. columellaris retained in the sieve were counted, and the density was calculated as individuals per square meter (ind $\mathrm{m}^{-2}$ ). Swash and backwash, flow in channels, suspension feeding, and sailing events (migration by snails employing their foot as an underwater sail) were documented on videos taken with digital cameras (DSC-H20, Sony, Tokyo, Japan) and analyzed using QuickTime Pro v7 (www.apple.com/quicktime).

\section{RESULTS}

Olivella columellaris is most easily observed when it is feeding in the backwash. The animals remain burrowed while the swash passes over them upwards on the beach slope. After the flow has reversed and the velocity of the backwash has decreased to such an extent that larger sediment particles are not transported anymore, the snails unfold their lateral appendages to expose the mucus sheets to the flow (Fig. 1). Evidently, $O$. columellaris cannot perform suspensionfeeding at high flow velocities (as reported for $O$. semistriata
Olivella columellaris (Sowerby 1825) y O. semistriata (Gray 1839) (Olivellidae, Caenogastropoda) son gasterópodos comunes de playas arenosas de la costa occidental de América tropical (Olsson 1956) con hábitos alimenticios inusuales. Ambas especies usan 2 pares de apéndices laterales-que no se encuentran en otros Olivellidae-para suspender películas de moco (mucus sheets) en el agua fluyente para capturar partículas (Troost et al. 2012). El moco, así como el plancton y detrito capturado, es consumido en intervalos cortos (Seilacher 1959). A la fecha, sólo se ha registrado esta forma de alimentación suspensívora en la zona de resaca de playas arenosas. Ya que esta zona se mueve con la marea, para una alimentación eficiente estos caracoles necesitan realizar migraciones mareales, lo cual ambas especies logran usando sus pies extendidos como velas bajo el agua. Parecía razonable interpretar esta navegación bajo el agua y la alimentación suspensívora como elementos funcionalmente vinculados de una adaptación específica a las condiciones en la zona intermareal de playas arenosas (Schuster 1952, Schuster-Dieterichs 1956, Seilacher 1959, Friedrich 1969: 270), lo que llevó a afirmar (Vanagt et al. 2008) que un reloj endógeno que marca los ritmos mareales es crucial para explicar los patrones de migración observados (todos estos autores confundieron $O$. semistriata y $O$. columellaris; ver Troost et al. 2012).

Es característico observar densidades extremas de O. columellaris en las playas al norte de Perú (Olsson 1924; comparar Ramírez et al. 2003). En este trabajo presentamos observaciones realizadas en esta región que sugieren que la migración y el comportamiento alimentario de esta especie son más versátiles de lo que se pensaba.

\section{MATERIALES Y MÉTODOS}

En agosto de 2013, se estudió O. columellaris durante viajes de campo en la costa del departamento de Piura, Perú, y se realizaron observaciones sistemáticas al norte del poblado de Colán $\left(4^{\circ} 59^{\prime} \mathrm{S}, 81^{\circ} 4^{\prime} \mathrm{W}\right)$. Para determinar las densidades locales, se insertaron tubos de plástico rígido (20 cm) de 28, 14 ó $10 \mathrm{~cm}$ de diámetro en el sedimento hasta una profundidad de $8 \mathrm{~cm}$. El contenido de los tubos se recolectó y se tamizó (5 mm luz de malla). Se contaron los individuos de $O$. columellaris retenidos en el tamiz y se calculó la densidad como individuos por metro cuadrado (ind $\mathrm{m}^{-2}$ ). Se tomaron videos con cámaras digitales (DSC-H20, Sony, Tokio, Japón) para documentar el flujo y reflujo de las olas, el flujo en los canales, la alimentación suspensívora y la migración de los caracoles usando su pie como vela bajo el agua. Los videos se analizaron con QuickTime Pro v7 (www.apple.com/quicktime).

\section{RESUltados}

Olivella columellaris se observa con mayor facilidad cuando se está alimentando en la zona de resaca. Los animales permanecen enterrados cuando el flujo del mar pasa sobre 
by Seilacher 1959). Consequently, the backwash periods during which suspension feeding is possible rarely exceed 20 s. At our study site at Colán, the density of $O$. columellaris in the backwash ranged from 1,000 to 20,000 ind $\mathrm{m}^{-2}$. In contrast, fewer than 10 ind $\mathrm{m}^{-2}$ were found above the highest reach of the waves at any stage of the tide, indicative of the efficiency of the animals' migration in the backwash zone.

Unexpectedly, we found suspension-feeding $O$. columellaris also under permanent water cover in lower beach zones. Here the snails expanded their mucus sheets when the incoming water flow stopped, and kept them exposed until the reversed seaward flow had picked up enough speed to transport sediment grains of significant size. This behavior has not been described before, presumably because its observation requires clear visibility in the lower swash zone, a rare condition. We observed it only with wave amplitudes below $20 \mathrm{~cm}$ around noon, when the sun stood high providing excellent illumination.

Olivella columellaris readily changes its migration behavior where the timing of the tidal progression is ellos. Cuando el flujo se invierte y la velocidad del reflujo disminuye de tal manera que las partículas de sedimento de mayor tamaño ya no son transportadas, los caracoles despliegan sus apéndices laterales para exponer las películas de moco al flujo (Fig. 1). Evidentemente, O. columellaris no puede llevar a cabo este tipo de alimentación a altas velocidades de flujo (como ha sido documentado para $O$. semistriata por Seilacher 1959). Consecuentemente, los periodos de reflujo durante el cual puede alimentarse raramente exceden 20 s. En nuestro sitio de estudio en Colán, la densidad de O. columellaris en la zona de resaca varió de 1,000 a 20,000 ind $\mathrm{m}^{-2}$. En contraste, se registraron menos de 10 ind $\mathrm{m}^{-2}$ más allá de la línea de mayor alcance de las olas durante cualquier etapa de la marea, lo que indica la eficiencia de la migración de los animales en la zona de resaca.

Inesperadamente, también observamos individuos de O. columellaris cubiertos permanentemente de agua alimentándose de partículas en suspensión en zonas inferiores de la playa. Aquí los caracoles expusieron las películas de moco cuando el flujo de agua entrante había parado y las

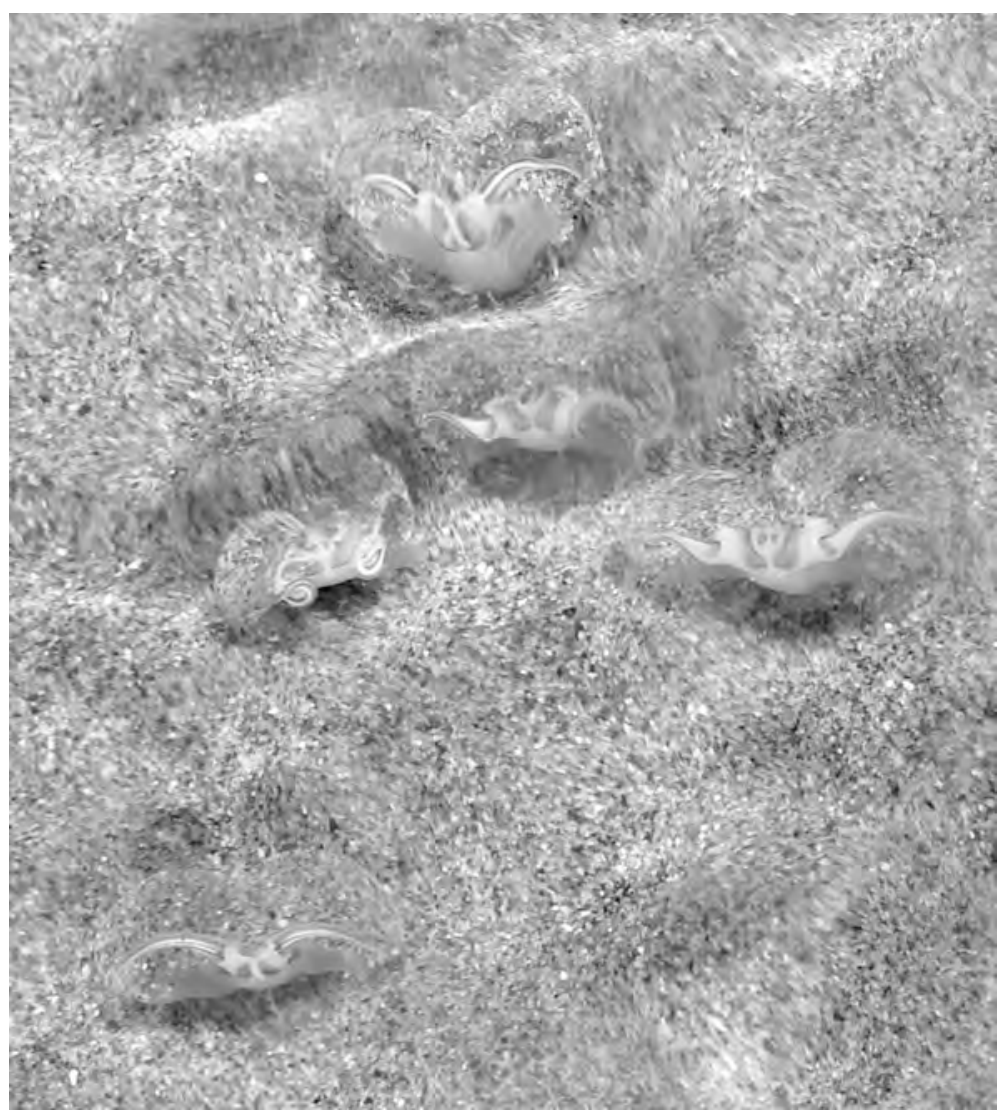

Figure 1. Olivella columellaris in its natural habitat near Colan, Peru, suspension-feeding in the backwash; flow direction is bottom to top. In these animals that are burrowed in the sand, only the propodium (most anterior portion of the foot) is visible. The propodial appendages suspend transparent mucus sheets, which the flow expands into a semispherical shape. Horizontal field width is $5 \mathrm{~cm}$.

Figura 1. Olivella columellaris en su hábitat natural cerca de Colán, Perú, alimentándose de partículas en suspensión en la zona de resaca; la dirección del flujo es de abajo a arriba. Sólo el propodio (porción anterior del pie) de estos animales enterrados en la arena es visible. Los apéndices propodiales suspenden películas de moco que el flujo expande en una forma semiesférica. La anchura del campo horizontal es $5 \mathrm{~cm}$. 
modified, as we repeatedly observed around artificial structures such as groins or jetties. We decided to document a representative case of such behavioral modification quantitatively. At our study site, several coast-parallel lines of boulders had been placed just below the high-water line to prevent erosion. At ebb tide, water from pools that had formed above these boulders streamed seaward, carving narrow channels of 1 to $4 \mathrm{~cm}$ depth into the tidal plain (Fig. 2a). Generally, the snails remained in these channels longer than on the adjacent plain. Suspension feeding correlated with seaward flow, and because the latter was extended in the channel compared to the plain, snails in the channel could feed longer (example shown in Fig. 2b, c). The animals on the plain responded to the comparatively poor feeding conditions at their location, and utilized the backwash to sail seaward while the snails in the channel did not (Fig. 2c). To evaluate the consequences of this behavior, we determined the density of the snails at the points defined in Figure $2 b$ at the end of the observational period documented in Figure 2c. At levels corresponding to the upper channel, there were no snails left on the plain $(P 1, P 2)$, while several hundred individuals per square meter were found in the channel $(C 1, C 2$; Fig. 2d). At the level at which the time-courses (Fig. 2c) had been determined, about 100 ind $\mathrm{m}^{-2}$ were still present on the plain (P3) but in the channel the density was over 10-fold higher (C3; Fig. 2d). Below the channel's lower end, densities were similar in the channel and plain (C4, C5, P4, P5; Fig. 2d). Similar observations were made in numerous flow channels, and periods of continuous feeding within channels in excess of 10 min were recorded repeatedly (Fig. 2e).

\section{DISCUSSION}

The existence and significance of endogenous tidal rhythms in some intertidal organisms cannot be doubted (Naylor 2010). It does not follow, however, that the behavior of intertidal creatures generally is controlled by endogenous circatidal clocks as implied, for example, by de la Iglesia and Johnson (2013). The assumption that an animal might benefit from or even require such an endogenous clock is plausible if the animal's life style is tightly related to the progression of the tides. This seemed to be the case in O. columellaris, which had appeared to depend on its ability to migrate with the backwash zone for its nutrition. Our observation of feeding animals in lower beach zones suggests that $O$. columellaris is capable of suspension feeding at any depth, if only the sediment surface experiences water flows of appropriate velocities. Thus, the linkage between feeding and tidal migrations in this species is not as strict as previously assumed. Moreover, animals in flow channels performed suspension feeding opportunistically as long as water currents permitted, and did not leave their locations unless feeding conditions deteriorated. Consequently, their tidal migrations were delayed, or even canceled. We have made analogous observations in numerous similar cases along the coast of north Peru. Our findings support the notion that tidal mantuvieron expuestas hasta que el reflujo del mar había alcanzado suficiente velocidad para transportar granos de sedimento de un tamaño significativo. Este comportamiento no ha sido descrito anteriormente, probablemente porque su observación requiere de clara visibilidad en la zona de vaivén inferior, lo cual no sucede con frecuencia. Fue posible observarlo sólo cuando la amplitud del oleaje era inferior a $20 \mathrm{~cm}$ al mediodía y el sol estaba alto y proporcionaba una iluminación excelente.

Olivella columellaris fácilmente cambia su comportamiento migratorio cuando se modifica el momento de la progresión de la marea, como observamos en varias ocasiones alrededor de estructuras artificiales como muelles o rompeolas. Decidimos documentar de manera cuantitativa un caso representativo de tal modificación de conducta. En nuestro sitio de estudio, se colocaron varias hileras de piedras grandes paralelas a la costa justo debajo de la línea de pleamar para evitar la erosión. Durante la marea menguante, el agua de los pozos que se habían formado por arriba de la línea de las piedras fluyó hacia el mar y formó canales de 1 a $4 \mathrm{~cm}$ de profundidad en la planicie mareal (Fig. 2a). Los caracoles generalmente permanecieron mayor tiempo en estos canales que en la planicie adyacente. La alimentación suspensívora se correlacionó con el flujo hacia el mar, y ya que el reflujo se extendió mayor tiempo en los canales que en la planicie, los animales pudieron alimentarse durante mayor tiempo (ver ejemplo en Fig. 2b, c). Los animales en la planicie respondieron a las condiciones de alimentación relativamente pobres y usaron el reflujo para migrar hacia el mar mientras que los animales en los canales no lo hicieron (Fig. 2c). Para analizar las consecuencias de este comportamiento, se determinó la densidad de los caracoles en los puntos definidos en la Figura 2b al final del periodo de observación documentado en la Figura 2c. En los puntos en la parte superior del canal, no se observaron caracoles en la planicie $(P 1, P 2)$, mientras que se registraron varios cientos de individuos por metro cuadrado en el canal (C1, C2; Fig. 2d). En los puntos inter-

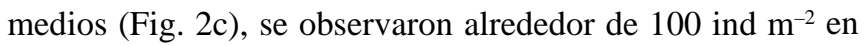
la planicie (P3), pero en el canal la densidad fue más de 10 veces mayor (C3; Fig. 2d). En los puntos por debajo de la parte inferior del canal, las densidades fueron similares en el canal y la planicie $(C 4, C 5, P 4, P 5$; Fig. 2d). Se realizaron observaciones similares en varios canales y en varias ocasiones se registraron periodos de alimentación continua de más de 10 min dentro de los canales (Fig. 2e).

\section{DISCUSIÓN}

No cabe duda de la existencia e importancia de los ritmos endógenos mareales en algunos organismos intermareales (Naylor 2010); sin embargo, esto no significa que el comportamiento de los animales intermareales es generalmente controlado por relojes endógenos que marcan ritmos mareales como lo han insinuado, por ejemplo, de la Iglesia y Johnson (2013). La suposición de que un animal puede beneficiarse o requerir tal reloj endógeno es posible si el estilo de vida del 


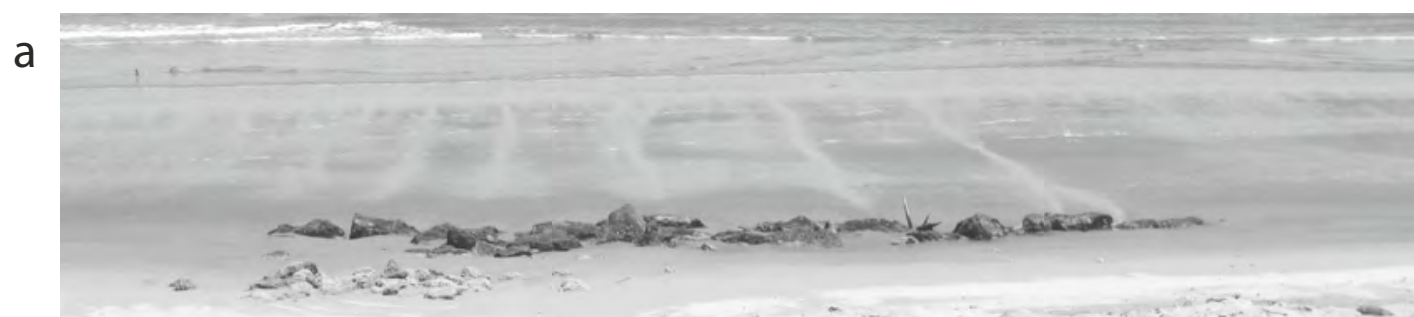

b

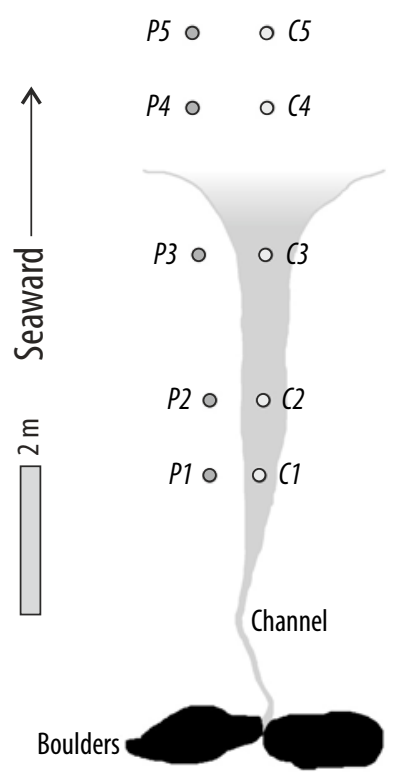

C
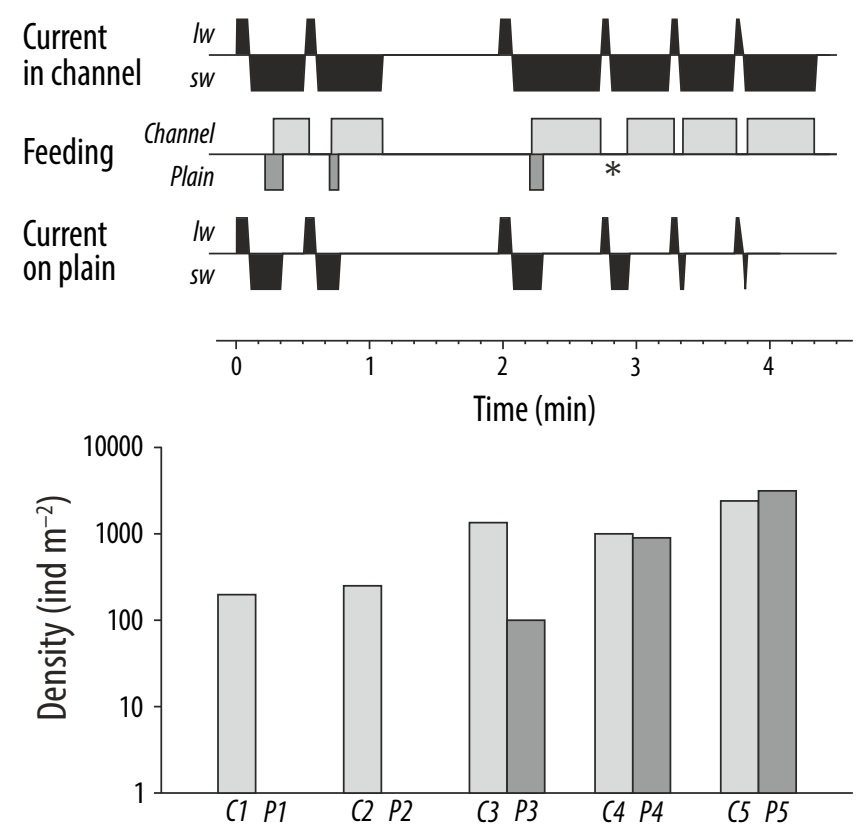

e

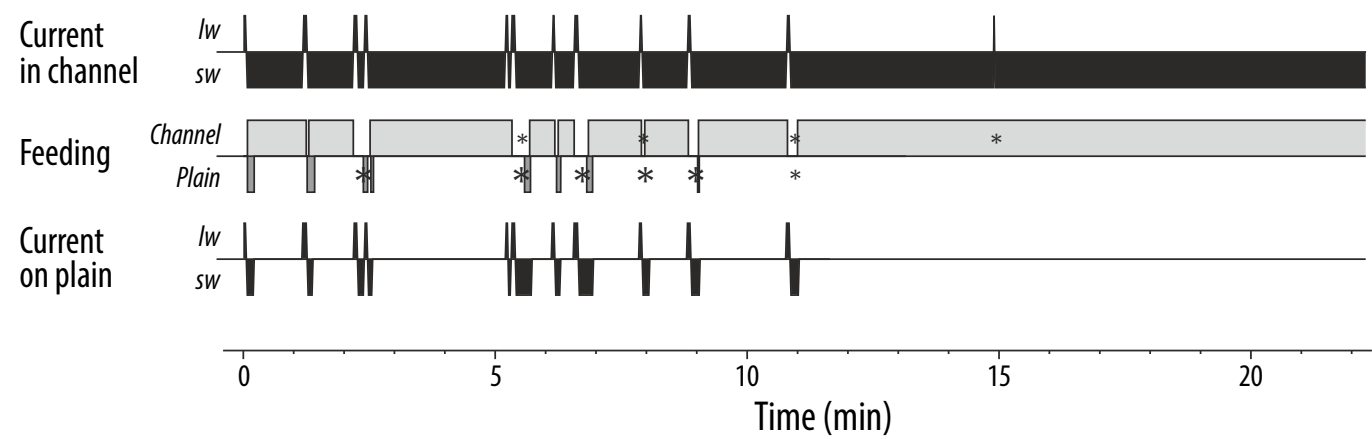

Figure 2. Opportunistic suspension feeding of Olivella columellaris. (a) Flow channels forming at retreating tide below a row of boulders; the horizontal width of the photograph is $19 \mathrm{~m}$ along its bottom edge. (b) Sketch (drawn to scale) of a flow channel in which the behavior of the snails was analyzed; the locations of 10 collection points for density determination are indicated. (c) Time-courses of water currents (lw, landward; sw, seaward) and feeding activity in the channel and on the plain at the positions marked C3 and P3 in (b). The asterisk indicates a sailing event: numerous snails emerged on the plain and sailed seaward with the backwash. (d) Densities of O. columellaris at the points defined in (b) at the end of the time-course in (c). (e) Time-course as in (c), showing almost continuous feeding activities in a channel over more than 20 min. Large asterisks: sailing events involving $>20$ snails; small asterisks: sailing events involving $<20$ snails.

Figura 2. Alimentación suspensívora oportunista de Olivella columellaris. (a) Canales que se forman durante el reflujo de la marea abajo de una hilera de rocas; el ancho horizontal de la fotografía es $19 \mathrm{~m}$ a lo largo de su borde inferior. (b) Bosquejo (dibujado a escala) de un canal de flujo en el cual se analizó el comportamiento de los caracoles; se indica la ubicación de los 10 puntos de recolección donde se determinó la densidad. (c) Trayectoria temporal de las corrientes de agua ( $l w$, hacia la tierra; $s w$, hacia el mar) y de las fases de la alimentación suspensívora en el canal y la planicie en las posiciones marcadas C3 y P3 en (b). El asterisco indica un evento de migración usando el pie como vela: varios caracoles aparecieron en la planicie y migraron hacia el mar con el reflujo del mar. (d) Densidades de O. columellaris en las posiciones indicadas en (b) al final de la trayectoria temporal en (c). (e) Trayectoria temporal, como en (c), que muestra la actividad de alimentación suspensívora casi continua en un canal durante más de 20 min. Asteriscos grandes: eventos de migración que incluyen $>20$ caracoles; asteriscos pequeños: eventos de migración que incluyen $<20$ caracoles. 
migrations in mollusks result from direct behavioral responses to changing conditions (McLachlan et al. 1979). If an endogenous circatidal clock should exist in $O$. columellaris (Vanagt et al. 2008), one would have to conclude that its influence on the behavior of the snails is easily overruled by external stimuli.

\section{ACKNOWLEDGMENTS}

This work was supported by a Pippert Science Research Award and a sabbatical leave granted to WSP by Indiana/ Purdue University Fort Wayne. We thank Lucía Delbene for translating the abstract into Spanish, and Benjamin Dattilo for helpful discussion.

\section{REFERENCES}

Ansell AD. 1983. The biology of the genus Donax. In: McLachlan A, Erasmus T (eds.), Sandy Beaches as Ecosystems. Dr W Junk Publishers, The Hague, pp. 607-635. http://dx.doi.org/10.1007/978-94-017-2938-3_46

Barnes RSK. 1986. Daily activity rhythms in the intertidal gastropod Hydrobia ulvae (Pennant). Estuar. Coast. Shelf Sci. 22(3): 325-334.

http://dx.doi.org/10.1016/0272-7714(86)90046-6

de la Iglesia HO, Johnson CH. 2013. Biological clocks: Riding the tides. Curr. Biol. 23(20): R921-R923. http://dx.doi.org/10.1016/j.cub.2013.09.006

Ellers O. 1995a. Behavioral control of swash-riding in the clam Donax variabilis. Biol. Bull. 189(2): 120-127. http://dx.doi.org/10.2307/1542462

Ellers O. 1995b. Discrimination among wave-generated sounds by a swash-riding clam. Biol. Bull. 189(2): 128-137. http://dx.doi.org/10.2307/1542463

Friedrich H. 1969 (reprinted 1973). Marine Biology. University of Washington Press, Seattle, 474 pp.

Little C, Nix W. 1976. The burrowing and floating behaviour of the gastropod Hydrobia ulvae. Estuar. Coast. Mar. Sci. 4(5): 537-544. http://dx.doi.org/10.1016/0302-3524(76)90028-1

McLachlan A, Hesp P. 1984. Faunal response to morphology and water circulation of a sandy beach with cusps. Mar. Ecol. Prog. Ser. 19: 133-144. http://dx.doi.org/10.3354/meps019133

McLachlan A, Wooldridge T, van der Horst G. 1979. Tidal movements of the macrofauna on an exposed sandy beach in South Africa. J. Zool. London 187(4): 433-442. http://dx.doi.org/10.1111/j.1469-7998.1979.tb03379.x

Naylor E. 2010. Chronobiology of Marine Organisms. Cambridge University Press, Cambridge, 242 pp.

Newell R. 1962. Behavioural aspects of the ecology of Peringia (= Hydrobia) ulvae (Pennant) (Gasteropoda, Prosobranchia). Proc. Zool. Soc. London 138(1): 49-75. http://dx.doi.org/10.1111/j.1469-7998.1962.tb05687.x

Olsson AA. 1924. Notes on marine mollusks from Peru and Ecuador. Nautilus 37: 120-130.

Olsson AA. 1956. Studies on the genus Olivella. Proc. Acad. Nat. Sci. Philadelphia 108: 155-225. http://www.jstor.org/stable/4064521

Ramírez R, Paredes C, Arenas J. 2003. Moluscos del Perú. Rev. Biol. Trop. 51 (Suppl. 3): 225-284.

Schuster O. 1952. Olivella columellaris un caracol de la Playa de Los Blancos. Comm. Inst. Trop. Invest. Cient., Univers. El Salvador 4: 10-13. animal está estrechamente relacionado con la progresión de las mareas. Tal parecía ser el caso de $O$. columellaris, que aparentemente dependía de su habilidad para migrar con la zona de resaca para su alimentación. Nuestra observación de los animales en las zonas inferiores de la playa sugiere que O. columellaris es capaz de alimentarse de partículas en suspensión a cualquier profundidad si la velocidad del flujo de agua sobre la superficie sedimentaria es adecuada. Por lo tanto, el vínculo entre la alimentación y las migraciones mareales de esta especie no es tan estricta como se suponía. Además, los individuos en los canales se alimentaban oportunamente mientras lo permitían las corrientes de agua y no abandonaban sus sitios a menos que se deterioraran las condiciones. Consecuentemente, se retrasaron o hasta cancelaron sus migraciones mareales. Hemos hecho observaciones análogas en varios otros sitios en la costa norte de Perú. Nuestros resultados apoyan la idea de que las migraciones mareales de los moluscus se deben a respuestas conductuales directas a condiciones cambiantes (McLachlan et al. 1979). $\mathrm{Si}$ existiera un reloj endógeno en $O$. columellaris (Vanagt et al. 2008), se tendría que concluir que su influencia en el comportamiento de los caracoles es fácilmente invalidada por estímulos externos.

\section{Agradecimientos}

Este trabajo fue apoyado con un premio a la investigación científica-Pippert Science Research Award-y una estancia sabática otorgada a WSP por la Universidad de Indiana/ Purdue en Fort Wayne. Agradecemos a Lucía Delbene su traducción del resumen al español y a Benjamin Dattilo su valiosa discusión.

Traducido al español por Christine Harris.

Schuster-Dieterichs O. 1956. Die Makrofauna am sandigen Brandungsstrand von El Salvador (mittelamerikanische Pazifikküste). Senckenbergiana Biol. 37: 1-56.

Seilacher A. 1959. Schnecken im Brandungssand. Natur u. Volk 89: 359-366.

Troost AI, Rupert SD, Cyrus AZ, Paladino FV, Dattilo BF, Peters WS. 2012. What can we learn from confusing Olivella columellaris and $O$. semistriata (Olivellidae, Gastropoda), two key species in panamic sandy beach ecosystems? Biota Neotrop. 12(2): 101-113. http://dx.doi.org/10.1590/S1676-06032012000200011

Vanagt T, Vincx M, Degraer S. 2008. Can sandy beach molluscs show an endogenously controlled circatidal migrating behaviour? Hints from a swash rig experiment. Mar. Ecol. 29(Suppl. 1): 118-125. http://dx.doi.org/10.1111/j.1439-0485.2008.00221.x

Vieira S, Coelho H, Nolasco R, Serôdio J, Barnes R, Queiroga H. 2010. The circatidal rhythm of the estuarine gastropod Hydrobia ulvae (Gastropoda: Hydrobiidae). Biol. J. Linn. Soc. 100(2): 439-450.

http://dx.doi.org/10.1111/j.1095-8312.2010.01428.x

Received January 2016, accepted October 2016. 